\title{
A DISCUSSION ON THE METHODOLOGY OF PEACE JOURNALISM
}

\author{
Ayça Demet ATAY \\ Faculty of Communication, Near East University, Cyprus \\ aycademetatay@gmail.com
}

\begin{abstract}
Peace journalism is a normative mode of journalism that aims to contribute to nonviolent transformation of conflicts. The theory, which supports that news about conflict should be given in a way to enhance empathy and understanding among adversaries, is referred to as a revolutionary or insurgent form of journalism by various sources. Peace journalism had an ambiguous start regarding its methodology, which seems to be related to the movement's pragmatic take-off in the late 1990's, and did not discuss its methodology until the mid-2000's. Later Jake Lynch (2006, 2007, 2014) proposed critical realism as the methodological foundation of the movement. This paper discusses the methodology problem of peace journalism and suggests instead a constructionist methodology, which is based on the premise that there is no truth independent of the observer; rather everything we know about the world is socially constructed. Critical realism prioritizes ontology over epistemology and argues that there is a certain shape of reality that one has to believe in. This paper argues that this transcendental ontology is a form of story-telling and there are thousands of ways of telling a story. Therefore, the priority for journalism should be on epistemology, that is to say, on the question of "how to know" as news is a representation of reality, and not a reflection of it.
\end{abstract}

Keywords: Peace journalism, methodology, critical realism, constructionism, epistemology

\section{BARIŞ GAZETECILİĞININ METODOLOJISİ ÜZERINE BİR TARTIŞMA}

ÖZ

Barış gazeteciliği çatışmaların şiddet dışı yollardan dönüştürülmesine katkıda bulunmayı amaçlayan normatif bir gazetecilik akımıdır. Çatışma haberlerinin taraflar arasında anlayış ve empatiyi güçlendirecek şekilde verilmesini savunan teori, farklı kaynaklarca devrimci ya da asi bir gazetecilik biçimi olarak adlandırılmaktadır. 1990'lı yılların sonlarında pragmatik bir çıkış yapan barış gazeteciliği, metodolojisiyle ilgili belirsiz bir başlangıç yaptı ve metodolojisini 2000'lerin ortalarına kadar tartışmadı. Daha sonra Jake Lynch $(2006,2007,2014)$ barış gazeteciliğinin metodolojik temeli olarak eleştirel gerçekçiliği önerdi. Bu çalışmada, barış gazeteciliğinin metodolojisi tartış1lıyor ve gözlemciden bağımsız bir hakikat bulunmadığı öncülüne dayanan, bunun yerine dünya hakkındaki tüm bildiklerimizin toplumsal olarak inşa edildiğini savunan inşacı bir metodoloji öneriliyor. Eleştirel gerçekçilik, ontolojiye epistemoloji üzerinde öncelik verir ve insanın inanması gereken, gerçeğin belirli bir şekli olduğunu savunur. Bu çalışma, bu aşkın ontolojinin bir öykü anlatma şekli olduğunu ve bir öyküyü anlatmanın binlerce yolu olduğunu savunuyor. Dolayısıyla, haber gerçeğin bir yansıması değil, bir temsili olduğu için, gazeteciliğin önceliği epistemoloji, bir başka ifadeyle, "nasıl bilinebilir" sorusu üzerine olmalıdır.

Anahtar sözcükler: Barış gazeteciliği, metodoloji, eleştirel gerçekçilik, inşacılık, epistemoloji

\section{INTRODUCTION}

Peace journalism is a normative theory which claims that news media have the responsibility and the capability of contributing to peaceful transformation of conflicts. In the introduction part of Lynch and McGoldrick's seminal book Peace Journalism, Roy Greenslade writes that "if media are the central locus of war-mongering then, logically, they have the capability to be the catalyst for peacemongering" (2005: ix). Greenslade's words point to the potential of the news media of playing a catalyst role for peace. This premise is the starting point of peace journalism, which aims to bring about change in the ways news is told about conflict. 
The theory is referred to as a "journalistic revolution" by Lynch and McGoldrick (2005) and, later, as an "insurgent form of journalism" by Lynch (2014), who have put outstanding effort into bringing the theory to the attention of the scholarly community and of professional journalists. The theory is described by Hackett as an "internal reform movement, operating in the corners of journalism education and news organizations" which aims "to revise professional practices" $(2011,2010)$. "Revolutionary/insurgent" and "reformist" are two different depictions of the same reality, that is to say, peace journalism.

Peace journalism had an ambivalent approach to methodology, which seems to be related to the peace journalism movement's pragmatic start in the 1990's. As Hanitzsch wrote in 2007 (2007), peace journalism did not define its epistemological foundation until the mid-2000s. In 2000's Lynch (2006, 2007) suggested critical realism as the methodological foundation of peace journalism, which he later further articulated upon (2014). In this paper, I will discuss the methodology of peace journalism and suggest a constructionist methodology for peace journalism.

\section{The story about the origins}

In several sources, mainly by Lynch, McGoldrick and Galtung, the origins of the story of peace journalism are dated back to Johan Galtung and Mari Holmboe Ruge's (1965) essay "The Structure of Foreign News". (See, for example, Lynch, 2010b; Lynch \& McGoldrick, 2010; 2012; Lynch \& Galtung, 2010; McGoldrick, 2011). In this early work, Galtung and Ruge analysed the structure of foreign news in Norwegian newspapers in an attempt to find an answer to the question of "how do 'events' become 'news'?", especially within the context of conflicts (Galtung \& Ruge, 1965: 65), and came up with policy implications including suggestions such as that "journalists should be better trained to capture and report on long-term developments and concentrate less on "events"; that there should be more coverage of "non-elite nations" and "non-elite people", and more reference to "nonpersonal causes of events" as well as to "positive events" (Galtung \& Ruge, 1965: 84-85).

Galtung, later, analysed with Vincent (1992) the flow of international news and developed a fourfactor news communication model that delved into the question of which international events made news. Accordingly, events that take place in elite nations have a greater chance of becoming news than events in non-elite nations; likewise events about elite people have a greater chance of being covered in news than those about non-elite people; events that can be personified and those with negative consequences have greater chance of becoming news (p.7). Ultimately, the ideal top news event is something negative, happening to an elite person affecting elites in an elite country (Lynch \& Galtung, 2010: 19).

In contrast to what is argued in the above mentioned sources, in these early works by Galtung and his various colleagues there is no reference to peace journalism. This form of history writing as a fixed and unchanging story points to a closure in the field, which creates dominance with regard to the founding fathers of the "idea".

Here, I would like to draw the attention of the reader to Stuart Hall's marks about cultural studies. In Cultural Studies and its Theoretical Legacies, he writes about the story of cultural studies in the following way: "I myself have told it many other ways before; and I intend to tell it in a different way later" (Hall, 1992: 227). Cultural studies does not have "one" history. There is no simple origin to it and its history is open to be rewritten over and over again.

Peace journalism is against dominance of all kinds, and hence, it should be self-critical regarding the potential of dominance this form of history writing may create within the field itself. Peace journalism as a field must remain open to constant change. There are always other ways of telling "what really happened". History is continuously written and re-written on the current day and projected upon the past. 


\section{The Peace/War Journalism Model}

Johan Galtung, in his binary model of peace versus war journalism, which he first presented at a summer school, targeting journalists, media academics and students in 1997 (Lynch, 1998), criticizes conventional media practices as "war journalism" and, applying conflict resolution principles to conflict reporting, comes up with a better way of conflict coverage, which he refers to as "peace journalism".

Accordingly, war journalism is violence-, propaganda-, elite-, and victory-orientated, whereas peace journalism is peace-, truth-, people-, and solution-orientated. War journalism presents conflicts as zero-sum games, with ultimately one party winning at the expense of the other's loss, whereas peace journalism supports that this doesn't have to be the case, and that there is always possibility for a winwin solution. In order to support nonviolent transformation of violent conflicts, peace journalism contends that news representations should make conflicts transparent in a way to enhance empathy and understanding among adversaries. Galtung advises journalists to view the conflict within its complete map with its historical and cultural roots, and to approach all sides with empathy reflecting the suffering of all parties. War journalism, he argues, is propaganda-orientated, in that it exposes "their" untruths, while covering up for "ours", peace journalism is, in contrast, truth-orientated and exposes the untruths of all sides. One of the criticisms that Galtung brings to "war journalism" is that it relies on elite sources, mainly on officials dominating the discourse about war and peace, without giving space to people peacemakers. Peace journalism suggests that those alternative voices for peace which are often left voiceless in conventional news media should be given adequate space. And finally, from a peace journalism perspective, peace is defined as "creativity + nonviolence", whereas war journalism views peace simply as "victory + ceasefire". What follows is that when weapons fall silent, war journalism leaves the scene, whereas peace journalism, as a process oriented approach, remains in the scene, following up for the aftermath of the peace agreement.

\section{A discussion on methodology}

Constructionism entails that "Things don't mean: we construct meaning, using representational systems - concepts and signs" (Hall, 1997b: 25). Gergen describes constructionism as a new "form of intelligibility" (1994: 78). Building upon his definition, I refer to constructionism as an invitation to "read" the world with an alternative lens.

Constructionism cautions us against "the taken-for-granted ways of understanding the world, including ourselves", and "invites us to be critical of the idea that our observations of the world unproblematically yield its nature to us, to challenge the view that conventional knowledge is based upon objective, unbiased observation of the world. It is therefore in opposition to what is referred to as positivism and empiricism in traditional science" (Burr, 2003: 2-3).

The starting point of the constructionist theory is the proposition that we can only know the world and act on it by means of language (Bilton, 2002: 63). Language is a precondition of thought, which sets the limits of people's interpretative repertoires in their meaning making activity, and it is not a "passive reporting medium" (Burr, 2003). Constructionist epistemology is based on the idea that there is no "truth" independent of the observer. Everything we know about the world, including ourselves is socially constructed. This is not to deny the existence of the material world ontologically. Rather, constructionists maintain that the meaning of the world is constructed within the web of discourses.

Following Saussure, constructionism claims that, as a representational system, "language is the privileged medium in which we 'make sense' of things, in which meaning is produced and exchanged" (Hall, 1997a: 1). Saussure analysed language as a representational system, and argued that every sign was composed of two further elements: the signifier and the signified. The signifier corresponds to the form as the actual word, image, photo, etc., which is associated with the signified, that is to say, the concept or idea one has in mind when one thinks of that object. Every time one hears, reads, or sees the signifier, it correlates with the signified (Hall, 1997b: 31). In the meaning production process, both the signifier and the signified are required, and "it is the relation between them, fixed by our cultural and linguistic codes, which sustains representation" (Hall, 1997b: 31). As 
Fuller notes, "the sign is the union of a form which signifies (signifier)... and an idea signified (signified). Though we may speak... as if they are separate entities, they exist only as components of the sign" (Fuller cited Hall, 1997b: 31).

Saussure argued that "In language there are only differences, and no positive terms" (1983: 118). Hence, words do not reflect reality in a mirror fashion. The relationship between the signifier and the signified is arbitrary, and meaning is constructed in relation to other signifiers. In the chain of signification, difference is what makes meaning possible. Derrida explains Saussure's notion of difference in Différance in the following way:

... the signified concept is never present in and of itself... every concept is inscribed in a chain or in a system within which it refers to the other, to other concepts, by means of systematic play of differences (1982: 11)

The signified is absent in the endless chain of signification. In other words, everything we know about the world is constructed within the web of representations through the infinite chain of significations. Thinking that things can have a meaning in themselves, and can be present to a knowing subject, is what Derrida refers as metaphysics of presence (Derrida cited in Game 1991: 12).

The meaning of each term in language depends on its relationship with other terms. Derrida coined the word différance, which means "difference and deferral of meaning", to explain the process of meaning construction in language. According to Derrida, difference "can never be wholly captured within any binary system. So any notion of a final meaning is always endlessly put off, deferred" (Hall, 1997b: 42).

As Derrida notes in That Dangerous Supplement, "the sign is always the supplement of the thing itself" (1997: 145). As such, "there is nothing outside of the text [there is no outside text]" (p. 158), and "...there has never been anything but writing" (p.159). From this perspective, news is a form of writing or a discourse, a representation of reality, which is produced in a process of signification, and not the reality itself.

We need meaning in order to make sense of the world. We do not "discover" the meaning of things; rather, we construct it within the web of discourses that is available to us in our culture. Therefore, "there is no pre-cultural real to be represented in knowledge" as Ann Game argues (1991: 7).

The positivist notion of objectivity is based on the claim that news reflects facts in a mirror fashion. Accordingly, the journalist needs to be objective, impartial and transparent for letting the facts speak for themselves. From a constructionist view, "facts" don't represent reality in themselves; rather, they are fictive, in the sense that they are produced by a discourse-user journalist situated within the news institutions that constitute part of the "truth regime" (Foucault, 1980) of a society.

Constructionism does not deny the existence of the extra-discursive world, which is explained by Laclau and Mouffe in the following way:

If there were no human beings on earth, those objects that we call stones would be there nonetheless; but they would not be 'stones', because there would be neither mineralogy nor a language capable of classifying them and distinguishing them from other objects" (Laclau and Mouffe, 1987: 84).

Laclau and Mouffe define discourse as a theoretical horizon on which objects are given a meaning and make a distinction between two forms of existence: esse (being) and ens (entity) (p.85). The esse of a physical object is historical and changing, the entity is not. Simply formulated, objects do exist "out there" independent of the observer, but they are only given meaning once they enter the horizon of discourse. Outside of any discursive context objects do not have being, they have only existence (p. 85). For example, the round shaped object covered with feather becomes a football only when it enters the horizon of discourse and establishes a system of relations with other objects, and these relations are socially constructed. This systematic set of relations is called as discourse (p. 82). 
The relationship between discourse, power and knowledge lies at the heart of the theory. If knowledge is not a direct derivation of reality, then how can it justify its claims to reality? Constructionist answer to the question is drawn upon Foucauldian conceptualisation of power/knowledge relationship. Foucault is mainly concerned with the politics of discourse rather than the production of meaning through representations. For Foucault, "truth isn't outside power" (1980: 131), rather is produced and reproduced in the circle of power relations. In Power/Knowledge he explains this relationship as such:

...truth isn't outside power, or lacking in power... Truth is a thing of this world: it is produced only by virtue of multiple forms of constraint. And it induces regular effects of power. Each society has its regime of truth, its 'general politics' truth: that is, the types of discourse which it accepts and makes function as true; the mechanisms and instances which enable one to distinguish true and false statements, the means by which each is sanctioned; the techniques and procedures accorded value in acquisition of truth; the status of those who are charged with saying what accounts as true. (p. 131)

According to Foucault, in modern societies, "truth" is centred on the form of scientific discourse; it is produced and transmitted under the control of a few great political and economic apparatuses, such as university, army, writing and media; it is circulated through the apparatuses of education and information; and it is the issue of political debate and social confrontation.

Foucault explores how the "truth regime" of a society disciplines people to think, feel and act in certain ways by setting the standards of normality through its institutions of knowledge. His conception of disciplinary power acts in a panoptic way, in which people are controlled by "freely subjecting themselves to the scrutiny of others, especially that of experts" (Burr, 1995: 72). Contrary to the sovereign power, which acts in the form of a chain, from top to bottom, which is monopolized by the state, the ruling class and so on, the disciplinary power circulates (Hall, 1997b: 49), in a way that it is dispersed in culture playing a pivotal role in shaping people's identities.

\section{Approaching news from a constructionist perspective}

From a constructionist standpoint, news does not reflect reality in a mirror fashion; rather news writing is a selection process. The journalist constructs her story selectively, including some "facts", while omitting others. Lynch and McGoldrick (2005) argue that the role of the peace journalist is a participant observer rather than a neutral outsider. In "the feedback loop" they criticize traditional journalism's linear view on conceptualizing cause and effect relations, and argue that the facts the journalist reports go back to the source and affect its possible future actions. Thus, the journalist inevitably intervenes in the course of events, and cannot claim to be a neutral outsider. Peace journalism situates the journalist as living interdependently, so to say, as being "in the boat" (Lesley Fordred cited in Lynch and McGoldrick, 2005: 240). The peace journalist is a part of the reality in which she re-constructs; her actions cause effects that return to the source, namely, the journalist herself. Therefore, journalism cannot be regarded as 'detached', as it is "implicated in cycles of cause and effect" (McGoldrick, 2011:140), and "one should take into account the foreseeable consequences of one's actions, [Weber] argued, and adjust one's behaviour accordingly" (Lynch \& McGoldrick 2005: 218)

The role of the journalist as a participant-observer in her story has attracted much criticism. The London based Institute for War and Peace Reporting (IWPR) criticised this participant-observer role as instrumentalisation of media by pushing the journalist from being a neutral observer in society to a direct actor. In a report, the IWPR announced that this type of instrumentalisation of media was a "dangerous violation of core professional principles". "Propaganda for peace is still propaganda", the report said (Institute for War and Peace Reporting, 2004: 168). Along similar lines, senior BBC correspondent David Loyn criticized Galtung for misunderstanding the role of journalists and drawing them into conflict situations as active participants, which compromises their integrity (2003). The journalist's role vis-à-vis her story is related to another, more encompassing debate, namely the question of objectivity. 
Peace journalism has had an ambivalent relationship with the notion of objectivity. Lynch declares in The Peace Journalism Option, that

For journalists, the illusion of objectivity is finished. In the past it was a cloak for a set of values and definitions underpinned by a broadly establishment world view. Now that view and the institutions which sustained it are fragmenting, it is becoming ever more clear that journalists' presence conditions the story they are covering, making objectivity impossible (1998).

Contrary to the above statement, Galtung argues that war journalism results from a distorted representation of reality whereas peace journalism is "truth-oriented" (Galtung, 2006: 1). The role of the peace journalist is to "expose untruths on all sides and uncover all cover-ups" (p.1). This conceptualization situates the journalist as an "eyewitness to the objective reality" and calls for conventional journalism ethic of objectivity to reach an undistorted representation of reality. As Hanitzsch rightly criticizes, news is not a "mirror" of reality, but rather a representation of the world, which is "based on cognition and contingent (re)construction of reality." In that respect, "to say that reality can be 'misrepresented' ... assumes that there is a proper and 'true' version of reality" (2007: $5)$.

Peace journalism's ambivalence regarding the notion of objectivity seems to be related to the its pragmatic start in the 1990s, which aimed to apply the knowledge accumulated in the fields of peace research and conflict resolution to journalism, in order to activate the potential of news media for "peace-mongering". Until mid-2000s, peace journalism movement did not define its epistemological foundation, as Hanitzsch (2007) wrote in 2007.

In Peace Journalism, Lynch and McGoldrick criticize objectivity, "as an ethos in journalism", which was "a phenomenon of the Enlightenment, and the political, economic and social changes imbricated with it" (2005: 203). They write that "three conventions of objective reporting are predisposed towards War Journalism" (p.209). These are "a bias in favour of official sources, a bias in favour of event over process, and a bias in favour of 'dualism' in reporting conflict". The notion of "we just report the facts", they contend, "presupposes a relationship between the facts and the report, the outside world and the way it is represented, which is natural, obvious and transparent. Hence the 'just'”(p.212).

In a search for an epistemology critical of what Hackett later referred to as the "objectivity regime" (2011), Lynch and McGoldrick, discuss structuralism and post-structuralism in their work, and ask the question of "Can Peace Journalism survive contact with deconstruction?"(2005: 221), giving the impression that they will propose a poststructuralist methodology for peace journalism.

Lynch and McGoldrick refer to Derrida's concepts of logocentrism and the 'transcendental signifier' and write that "deconstruction is sometimes criticised as a suggestion that we cannot, finally, 'know' anything- removing any basis to differentiate reliably between fact and fiction" (2005: 222). Their answer to this criticism is "no". They then discuss Derrida's concept of transcendental signifier which enables one "to inspect from the outside something called logocentrism" (p.222). "Many western ways of thinking, including those apparently antagonistic- liberalism and Marxism, for instance," they write, "shared one key characteristic: each was centred on its own single concept or logos, left sacrosanct as the underpinning for the entire system of signification and the meanings- and binary oppositions- therein" (p.222). This transcendental signifier, which constitutes the centre of a structure, may it be God, Reason, Progress or Class, can be, after all, under deconstruction. Lynch and McGoldrick (2005) quote Derrida saying that "the notion of a structure lacking any centre represents the unthinkable itself" (Derrida cited in p.222), and they write that, "Derrida eventually nominated his own candidate for a 'transcendental signifier', something we need not attempt to deconstruct, or try to prove it is deconstructing itself" (p.222). Lynch and McGoldrick, at the end of their discussion on deconstruction, come up with their own nominee for a transcendental signifier, namely, peace, which would rest on the premises of "justice and emancipation along with the principles of non-violence and creativity", and which would provide a "vantage point from which to observe and report" (p.222). 
I agree with Lynch and McGoldrick in that we need a vantage point in our search for "truth". Here, I point to a historical form of universal protonorm that is "embedded across space than being absolutist over time" (Christians, 2011: 395) as a starting point. With a twist on Spivak's (1988) concept of strategic essentialism, I have referred to this approach as strategic universalism (Atay, 2016: 193). As Spivak's (1988) conception of strategic essentialism, strategic universalism can be conceptualized as a temporary strategy for resistance, as a strategic starting point for intellectual work not to fall into endless relativism. Such strategic universalism would provide journalists who are participant observers to their stories with an ethical anchorage, "a strategic 'outside' for them to be self-critical" (Atay, 2016: 193).

\section{Critical realism as the methodology for peace journalism?}

Lynch $(2006,2007,2014)$ has suggested critical realism as the methodological foundation of peace journalism, and Hackett (2011), has presented it as a "challenger paradigm" to conventional journalism's "objectivity regime", which, he has argued, rests on a positivist understanding of news as an accurate description of the world as it is. Hackett contends that peace journalism, in contrast, rejects both the positivist and relativist positions and situates itself in a critical realist epistemology without renouncing a commitment to truthfulness (pp. 42-43), which challenges the objectivity regime "towards an ethos of dialogue and an epistemology of self-reflexivity" (p.63).

From the standpoint of pure conventionalism, news is "what is happening" (Loyn, 2003), and "good journalism" is an honest attempt to fact-based reporting of the discernible truth written clearly for its readers whoever they may be (Randall, 2011). Hence journalists are situated as eye-witnesses to truth (Loyn, 2003). This pure notion of "truth", however, has been problematised even by strong advocates of objectivity such as Loyn himself. In Witnessing the Truth, Loyn argues;

There cannot of course be a single absolute truth- anyone who has ever interviewed two observers of the same incident knows that there is no perfect account-but once we step away from pursuing the truth, then we are lost in moral relativism that threatens the whole business of reporting... There is no objective truth...objectivity has to remain a goal, the only sacred goal we have. Just pursuing the ideal is enough, although we know, because of the shifting sand we live on, that an absolute objectivity is impossible... But both the reporter and the audience need to know that there is no other agenda- that what you see on the screen or hear on the radio is an honest attempt at objectivity (2003).

The "shifting sand" metaphor in Loyn's discourse points to an epistemological crisis related to the notion of objectivity. As Loyn later contends "perfect truth is unattainable", yet the "pursuit of an ideal is surely philosophically coherent, even though we know that will fall short" (2007: 3).

Critical realism presents a mid-way between the realist and constructionist positions. As Hanitzsch (2004) argues, Galtung's realist position claims "the observer and the observed as two distinct categories and assumes that reality, in principle, can be perceived and described "as it is". Descriptions of journalism that have their origin in this paradigm are primarily critical on the nature of mass media. Their message is "The media distort reality" (p.488). "From a constructivist perspective", Hanitzsch writes, "the observer and the observed appear as inseparable categories. As a result, "reality" - or what we believe to be reality- emerges from the consciousness of the observer. This implies for the description of journalism that both journalists and recipients construct their reality actively and autonomously" (p.488). In that respect, a constructionist perspective disapproves the notion "that the "objectiveness" of a certain news account can be measured by its degree of correspondence with the genuine reality" (p. 488).

As mentioned above, critical realism presents a midway between these two positions. Quoting Wright, Lynch defines critical realism as

A way of describing the process of 'knowing' that acknowledges the reality of the thing known, as something other than the knower (hence 'realism'), while fully acknowledging that the only access we have to this reality lies along the spiralling path of appropriate dialogue or 
conversation between the knower and the thing known (hence 'critical') (Wright cited in Lynch, 2006:74).

"On a critical realist view", Lynch writes, "news should still be seen as a representation of something other than itself- a 'report of the facts', even though those facts are, in nearly every case, readymediated by the time any journalist, let alone readers and audiences, comes into contact with them" (p.74).

Lynch suggests critical realism as the epistemology of "good journalism", in that critical realism acknowledges that "reality exists independently of our knowledge of it', and although this knowledge is always fallible, because the outside world is not fully transparent, it is possible through discussion and deliberation in public spheres to recognise that 'all knowledge is not equally fallible"' (Danermark, Ekström, Jakobsen, \& Karlsson cited in Lynch, 2014: 30).

Critical realism prioritizes ontology over epistemology. Bhaskar claims that "there is no getting away from ontology":

You can't get away without ontology. It is not a question of being a realist or not a realist. It is a question of what kind of realist you are going to be - explicit or tacit. Insofar as you are not a realist, you secrete an ontology and a realism... You can't get far in the world unless you are implicitly realist in practice (Norris, 1999).

Critical realist methodology is based on a transcendental ontology that assumes the extra-discursive world has a certain shape, and it is very important to get its shape right (Laclau \& Bhaskar, 2007). This transcendental ontology presupposes that the world is structured, and that it is governed by a multiplicity of contradictory and, at times, antagonistic transfactual laws and tendencies. As Bhaskar points out, "when you argue from a transcendental premise, you are arguing from something you have to believe" (Laclau \& Bhaskar, 2007: 12).

Critical realism aims at preserving the unity of social and natural sciences, and the authority of science against the wave of uncertainty that came along with discovery of the limits of Newtonian physics. It does that by updating its propositions on ontology, i.e. on the real nature of being and absence. In an attempt to "reconcile" (Norris, 1999) Cartesian binaries that dominated contemporary human sciences, such as reason/cause, mind/body, fact/value, etc., critical realism stratifies the notion of reality itself into three: real, actual, and empirical. The stratum of real refers to objects, their structures or natures and their causal powers and liabilities; the stratum of actual refers to what happens when these powers and liabilities are activated; and the stratum of empirical is the subset of the real and actual that is experienced by human actors (Fairclough, Jessop and Sayer, 2004).

Here, I would like to ask some questions: why do we have to presume that the extra-discursive world has a certain shape? Do we need a transcendental ontology to which we have to believe in? Can't we simply argue that our knowledge of the world is dependent on discourse and presuppose a transcendental ontology?

\section{Conclusion}

Peace journalism had a pragmatic start, which aimed to apply the knowledge produced in the fields of peace research and conflict resolution to news reporting in order to activate the media's potential for peace-mongering. Until the mid-2000s the problem of methodology had not been discussed within the field.

Coming from a realist position Galtung criticizes conventional war reporting for distorting reality and suggests that journalism should be truth-orientated, situating the journalist as an eyewitness to objective reality. This approach is based on the proposition that there is a true version of reality, in other words, truth exists independent of the observer.

Later Jake Lynch proposed critical realism as the methodology for peace journalism, which is based on the premise that reality exists independent of the observer yet the only access to this reality is 
through a "spiralling path of appropriate dialogue or conversation" between the observer and the observed.

Critical realism prioritizes ontology over epistemology and argues that reality has a certain shape that one has to believe in, while constructionism focuses more on epistemology than ontology, and deals with the question of "how we can know." This is a relevant question to journalism, which is about reporting representation of reality. News is just a representation; it is a construction of reality by the journalist. In many cases the news is constructed before it reaches the journalist. But even we suppose that the journalist is an eyewitness to her story, the knower/journalist does not reflect reality / the facts, but rather she constructs the meaning of what is happening with reference to her discursive interpretive repertoire. Therefore, the "how to know" question of epistemology should be prioritized in journalism over the "what exists" question of ontology, as "there is no pre-cultural real to be represented in knowledge" (Game, 1991:7). Outside language and discourse, there is no meaning. The transcendental ontology of critical realism is a form of story-telling about reality, and there can be many ways of telling a story.

As mentioned earlier, peace journalism is against dominance. Thus it should be self-critical about the dominance it may create within itself. There is a difference between proposing "a" methodology for peace journalism than proposing "the" methodology for it. This paper attempted to discuss constructionism as a methodology for peace journalism. The story is open to be written and rewritten again...

\section{REFERENCES}

Atay, A. D. (2016). Communicating with the Other: Peace Journalism as a Form of Self-Other Relationship. Journal of Media Ethics, 31(3), 188-195.

Bilton, T. (2002). Introductory Sociology. Basingstoke: Palgrave Macmillan.

Burr, V. (1995). An Introduction to Social Constructionism. London and New York: Routledge.

Burr, V. (2003). Social Constructionism (2nd ed.). London and New York: Routledge.

Christians, C. G. (2011). Journalism Ethics in Theory and Practice. In G. Cheney, S. May, \& D. Munshi (Eds.), The Handbook of Communication Ethics (pp. 190-203). New York and Oxon: Routlegde.

Derrida, J. (1982). Différance. In Margins of Philosophy (A. Bass, Trans., pp. 3-27). Chicago: University of Chicago Press.

Derrida, J. (1997). ...That Dangerous Supplement... In J. Derrida (Ed.), Of Grammatology (pp. 141164). Baltimore and London: The John Hopkins University Press, Corrected Edition.

Fairclough, N., Jessop, B., \& Sayer, A. (2004). Critical Realism and Semiosis. In J. Joseph, \& J. M. Roberts (Eds.), Realism Discourse and Deconstruction (pp. 23-42). London and New York: Routledge.

Foucault, M. (1980). Power/Knowledge: Selected Interviews and Other Writings, 1972-1977. New York and London: Harvester Wheatsheaf.

Foucault, M. (1984). What is an Author? In P. Rabinow (Ed.), The Foucault Reader (pp. 101-120). New York: Pantheon Books.

Galtung, J. (2006). Peace Journalism as an Ethical Challenge. Global Media Journal: Mediterranean Edition, 1(2), 1-5.

Galtung, J., \& Ruge, M. H. (1965). The Structure of Foreign News. Journal of Peace Research, 2(1), 64-91.

Galtung, J., \& Vincent, R. C. (1992). Global Glasnost: Toward a New World Information and Communication Order? Cresskill, NJ: Hampton Press.

Game, A. (1991). Undoing the Social towards a Deconstructive Sociology. Toronto: University of Toronto Press.

Gergen, K. J. (1994). Realities and Relationships: Soundings in Social Construction. Cambridge, Massachusetts and London: Harvard University Press.

Greenslade, R. (2005). Introduction. In J. Lynch, \& A. McGoldrick, Peace Journalism (pp. ix-xi). Stroud: Hawthorn Press .

Hackett, R. A. (2010). Journalism for Peace and Justice: Towards a Comparative Analysis of Media Paradigms. Studies in Social Justice, 4(2), 179-198. 
Hackett, R. A. (2011). New Vistas for Peace Journalism: Alternative Media and Communication Rights. In I. S. Shaw, J. Lynch, \& R. A. Hackett (Eds.), Expanding Peace Journalism (pp. 35-69). Sydney: Sydney University Press.

Hall, S. (1992). Cultural Studies and its Theoretical Legacies. In L. Grossberg, C. Nelson, \& P. Treichler (Eds.), Cultural Studies (pp. 277-294). New York and London: Routledge.

Hall, S. (1997a). Introduction. In S. Hall (Ed.), Representation: Cultural Representations and Signifying Practices (pp. 1-11). London, Thousand Oaks and New Delhi: Sage Publications in association with The Open University.

Hall, S. (1997b). The Work of Representation. In S. Hall (Ed.), Representation: Cultural Representations and Signifying Practices (pp. 13-74). London, Thousand Oaks and New Delhi: Sage Publications in association with The Open University.

Hanitzsch, T. (2004). Journalists as Peacekeeping Force? Peace Journalism and Mass Communication Theory. Journalism Studies, 5(4), 483-495.

Hanitzsch, T. (2007). Situating Peace Journalism in Journalism Studies: A Critical Appraisal. Conflict \& Communication Online, 6(2), 1-9.

Institute for War and Peace Reporting. (2004). Reporting for Change: A Handbook for Local Journalists in Crisis Areas. Retrieved May 8, 2013, from Institute for War and Peace Reporting: http://iw3.iwpr.net/sites/default/files/iwpr_training_manual_english.pdf

Laclau, E., \& Bhaskar, R. (2007). Discourse Theory vs Critical Realism. Journal of Critical Realism, 1(2), 9-14.

Laclau, E., \& Mouffe, C. (1987). Post-Marxism without Apologies. New Left Review, I(166), 79-106. Loyn, D. (2003, February 20). Witnessing the Truth. Retrieved November 21, 2014, from Open Democracy: http://www.opendemocracy.net/media-journalismwar/article_993.jsp.

Loyn, D. (2007). Good Journalism or Peace Journalism? Conflict \& Communication Online, 6(2), 1 10.

Lynch, J. (1998). The Peace Journalism Option. Retrieved January 11, 2016, from Global Issues: http://www.globalissues.org/article/534/the-peace-journalism-option\#ThePeaceJournalismOption Lynch, J. (2006). What's so Great about Peace Journalism? Global Media Journal: Mediterranean Edition, 1(1), 74-87.

Lynch, J. (2007). Peace Journalism and its Discontents. Conflict \& Communication Online, 6(2), 113.

Lynch, J. (2010b). Peace Journalism. In S. Allan (Ed.), The Routledge Companion to News and Journalism (pp. 542-553). London and New York: Routledge.

Lynch, J. (2014). A Global Standard for Reporting Conflict. New York and London: Routledge.

Lynch, J., \& Galtung, J. (2010). Reporting Conflict: New Directions in Peace Journalism. St.Lucia, Queensland: The University of Queensland Press.

Lynch, J., \& McGoldrick, A. (2005). Peace Journalism. Stroud: Hawthorn Press.

Lynch, J., \& McGoldrick, A. (2010). A Global Standart for Reporting Conflict and Peace. In R. L. Keeble, J. Tulloch, \& F. Zollmann (Eds.), Peace Journalism, War and Conflict Resolution (pp. 87103). New York: Peter Lang Publishing.

Lynch, J., \& McGoldrick, A. (2012). Responses to Peace Journalism. Journalism, 14(8), 1041-1058.

McGoldrick, A. (2011). Empathy and Ethics: Journalistic Representation and its Consequences. In I. S. Shaw, J. Lynch, \& R. A. Hackett (Eds.), Expanding Peace Journalism (pp. 122-144). Sydney: Sydney University Press.

Norris, C. (1999). Roy Bhaskar Interviewed. Retrieved January 9, 2016, from The Web Site for Critical Realism: http://www.criticalrealism.com/archive/rbhaskar_rbi.html

Randall, D. (2011). The Universal Journalist (Fourth ed.). London: Pluto Press.

Saussure, F. (1983). Course in General Linguistics. London : Duckworth.

Spivak, G. C. (1988). Can the Subaltern Speak? In C. Nelson, \& L. Grossberg (Eds.), Marxism and the Interpretation of Culture (pp. 271-313). Champaign: University of Illinois Press. 